\title{
エポキシマイカ絶縁の機械的疲労による 絶縁劣化特性
}

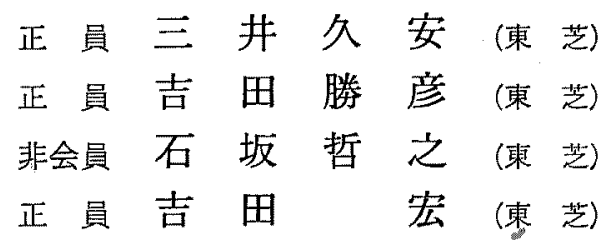

\section{1. まえがき}

タービン発電機，水車発電機，高電正電動機，一般 産業用直流機などの大形回転機は，大容量化するにつ れ鉄心長が長くなり，運転温度す上がる傾向にある。 また近年, 省資源, 省エネルギーの必要性加 , 負荷 調整運転する機会が增え，起動・停止の頻度が高くな る傾向がある。回転機に使われるエポキシマイカ絶縁 は学体や鉄心と熱膨張率が異なり，それぞれの温度む 均一ではないため, 起動・停止時に熱機械応力が発生 し，てれが繰返されると疲労劣化が起きやすくなる。 一方，起動時や運転中，また短絡時などにはコイルに 電磁力が働き振動する。とのため絶縁層が振動による 疲労劣化を起こす。近年，回転機の小形化を意困し， コイル1本あたりに流れる電流を増し，運転温度を上 げる一方，絶縁厚を削隇する傾向にある。このため絶 縁層に加わる振動による機械的ストレスが大きくなる と共に痩学出化が起きやすくなってきている。著者ら は，乙のような観点加ら，回転機に使われるエポキシ マイカ絶緣の熱機械応力ならびに振動による波労少化 特性の把握汇努めてきだ(1) (4)。

ここでは, 絶縁酋の切出し片を使った疲学試験の結 果を基に，別に行なった実規模のタービン発電機コイ ルのヒートサイクル試験格よびコイル絶䋑の繰返し曲 げ疲労試験の結果について検討した。その結果, 通常

Degradation Characteristics due to Mechanical Fatigue of Epoxy Micaceous Insulations. By Hisayasu Mitsui, Member, Katsuhiko Yoshida, Member, Takashi Ishizaka, Non-member \& Hiroshi Yoshida, Member (Toshiba Corporation).

三非入安：正買，(楼)東芝

志田勝彦：正員，(株)查芝

石坆哲之：非会圆，(林)東之

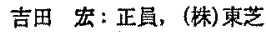

回転機が使われる温度条件では，コイル絶縁は引張り より王縮による波学が起きやすいとと，また一定変位 の繰返し曲げ試験においては，絶縁層の弾性率が急激 に低下し始める温度付近で疲学が極大となる現象が見 られることなどが明らかになった。

\section{2. 試料および試験方法}

〈2・1〉 絶縁層の切出し片による引張りおよひ圧縮 疲労特性 図 1 亿示すように，断面が $10 \mathrm{~mm} \times 50 \mathrm{~mm}$ のアルミニゥム板に離型用のポリテトラフルオルエチ レン(PTFE) テープを巻回したのち, マイカテープを $1 / 2$ 重巻きし, エポキシ樹脂を真空加圧含漫し加熱硬 化したモデルバーコイルを作製した。

このコイルから，切削加工により図2のような形の 絶縁首を試料として切出した。試験に用いた絶縁は表 1の (1)〜3に示すような楧成である。引張り疲労試 験の場合，テープ幅の影響を調へるために，絶縁 (3) に ついて $10 \mathrm{~mm}$ 幅(3)A, $32 \mathrm{~mm}$ 幅 (3)B), 平巻き (3) の試料を用意した。また，絶縁層中のボイドの影響を 調べるために，マイカテープ幅が $32 \mathrm{~mm}$ の絶縁 (3)の 中央部の一層に厚さ $25 \mu \mathrm{m}$, 幅 $21 \mathrm{~mm} の \mathrm{PTFE}$ テ 一プを $21 \mathrm{~mm}$ ずつ飛ばし巻きした試料 (3) む) 用意 した。疲学試験は 第宮製作所製油圧サーボ EFH-100

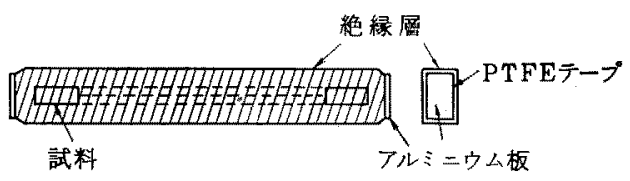

図 1 絶縁層加らの試料の切出し方法

Fig. 1. Method of cutting-out specimens from insulation wall. 


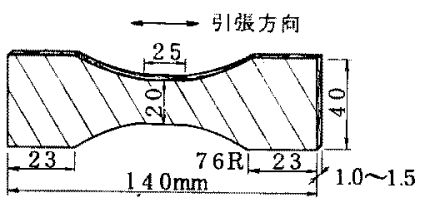

(a)引張疲学試験

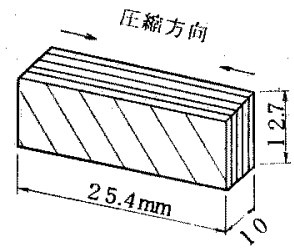

(b) 压粳疲学試験

园 2 試料の形状と応力を加えた方向

Fig. 2. Shape of specimens and stress applied directions.

表 1 試料の絶縁構成

Table 1. Insulation structure of specimens.

\begin{tabular}{|c|c|c|c|c|c|}
\hline \multirow{2}{*}{ 鈿绿 } & \multicolumn{3}{|c|}{ マイカテーブ } & \multirow{2}{*}{ 含漫樹脂 } & \multirow{2}{*}{ 䊉縁システム } \\
\hline & マイカ & 補強材 & 接福剂 & & \\
\hline (1) & $M_{1}$ & \multirow{3}{*}{$G_{1}$} & $E_{1}$ & $E_{5}$ & \multirow{3}{*}{$\begin{array}{l}\text { VPI (傎空加压 } \\
\text { 含浸) 方式 }\end{array}$} \\
\hline (2) & \multirow{2}{*}{$M_{2}$} & & $E_{2}$ & \multirow{2}{*}{$E_{8}$} & \\
\hline (3) & & & $E_{3}$ & & \\
\hline (4) & $M_{3}$ & \multirow{3}{*}{$G_{2}$} & \multirow{3}{*}{$E_{4}$} & & \multirow{3}{*}{$\begin{array}{l}\text { レシンリッチ方式 } \\
\text { (液王硬化方式) }\end{array}$} \\
\hline (5) & $M_{\mathbf{3}}+F$ & & & & \\
\hline (6) & $F$ & & & & \\
\hline
\end{tabular}

を使い，定荷重方式で，繰返し周波数 $1 \mathrm{~Hz}$ の正弦波 により引張りおよび王縮試験を行なった。応力はコイ ルのヒートサイクルや振動により生ずる応力の方向を 考虑して, 図 2 に示すようにコイルの長手方向に相当 する方向に加えた。なお，繰返し応力の大きさは応力 振幅 $\sigma_{a}$ で表わした。ここで， $\sigma_{a}=1 / 2 \cdot\left(\sigma_{1}-\sigma_{2}\right)$ で, $\sigma_{1}, \sigma_{2}$ はそれぞれ上限応力, 下限応力であり， $\sigma_{2} \fallingdotseq 0$ だある。

〈2・2〉実規模コイルによるヒートサイクル劣化特 性表1の絶縁(1)〜3)を施した $22 \mathrm{kV}-600 \mathrm{MW}$ 級 タービン発電機コイルを, 長さ $6.6 \mathrm{~m}$ の鉄心に装着 し，通電による加熱と扇風機による冷却により，45ㅇ ↔ $160^{\circ} \mathrm{C}$ のヒートサイクル試験を行なった ${ }^{(2)}$ 。ヒート サイクルによる絶縁性状の変化を調べるために，シェ ーリングブリッジにより電圧一 $\tan \delta$ 特性を測定した。 また試験終了後絶縁破壊試驗を行ない, 絶縁破壊箇所 近傍の絶縁層を走查形電子顕微鏡 (SEM) そより観察

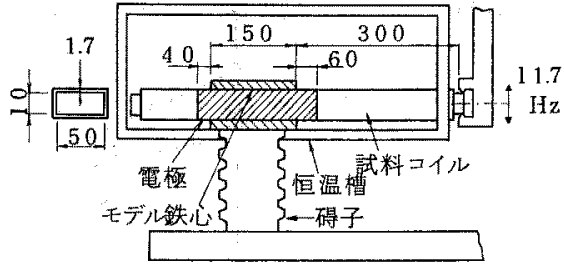

図 3 絽返し曲げ疲学試験装置

Fig. 3. Test setup for repeated bending fatigue test.

した。

$\langle 2 \cdot 3\rangle$ 繰返し曲げ疲労特性 $10 \mathrm{~mm} \times 50 \mathrm{~mm} \times$ $800 \mathrm{~mm}$ のアルミニゥム板に表1 亿示す絶緑（厚さ約 $1.7 \mathrm{~mm})$ を施したモデルバーコイルを陚料とした。

图3に示すように，試料を恒温槽に入れ，中央部を 固定し，片端を振動させた(1)。振動は $11.7 \mathrm{~Hz}$ で主に 両振りで行なったが，一部片振りによる試験す行なっ た。また，振幅の大きさを変え変位量の影響について あ調べた。なお，図了の装置では高温の場合は試料の 長さ方向に温度こう配ができるので, 陚料の温度を均 一にするため駆動装置を含め環境試験室に入れた試験 あ行なった。振動を加えたコイルの中央部 $250 \mathrm{~mm}$ に 銀ペイントを塗り，室温の油中にて $1 \mathrm{kV} / \mathrm{s}$ の昇圧速 度で短時間破塄電任 (BDV) を求めた。

\section{3. 試験結果および考察}

〈3.1〉 絶縁層の切出し片による引張りおよび住樎 疲労特性図4 亿絶縁 (1) (3) D 25,80,120,160 ${ }^{\circ} \mathrm{C}$ 亿おける引張り疲労特性を示す。応力振幅 $\sigma_{a}(\mathrm{~kg} /$ $\mathrm{mm}^{2}$ ) と破断までの繰返し数 $N$ (回) は雨対数紙上で 直楾近似でき，次の(1)式で表わすととのできる関係 があるととがわかる。

$$
\begin{aligned}
& N=k \sigma_{a}{ }^{\alpha} \ldots \ldots . . . . . . \\
& \text { ただし， } k, \alpha: \text { 定数 }
\end{aligned}
$$

また，温度が高くなるほど疲労しやすくなり， $25^{\circ} \mathrm{CK}$ 比べ高温の場合のほうが各絶縁の引張り疲労特性の差 が顕著に見われるととがわかる。

絶縁 (4) (6) の引張り疲労特性を図 5 亿示す。これ からマイカの構成が全集成マイカ>集成マイカ・はが しマイカ混用>全はがしマイカの順に疲労特性が偕れ ていると言える。乙れは試料を切出す際にはがしマイ 力部分が損慯を受けやすいとともあるが、はがしマイ カの場合，へき開性があるのできれつが生じやすいた めと考觉られる。

図 6 に, 絶縁 (3)における引張り疲労特性に及ぼすテ ープ幅の影響および PTFE テープ巻込みの影響を調 


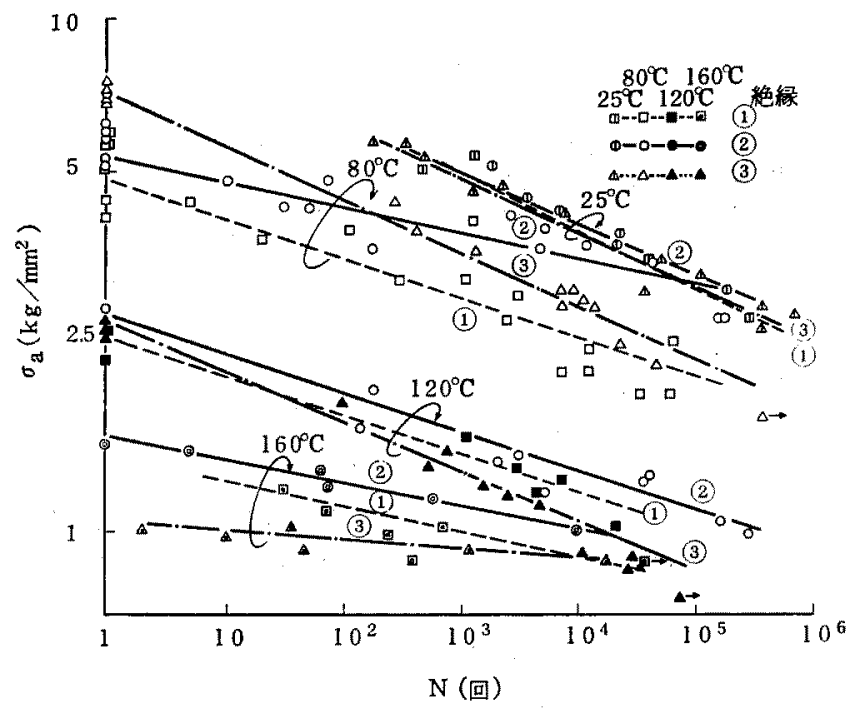

因 4 絶縁 (1) 〜 (3)の引張り疲労特性

Fig. 4. Tensile fatigue characteristics of insulations (1) (3).

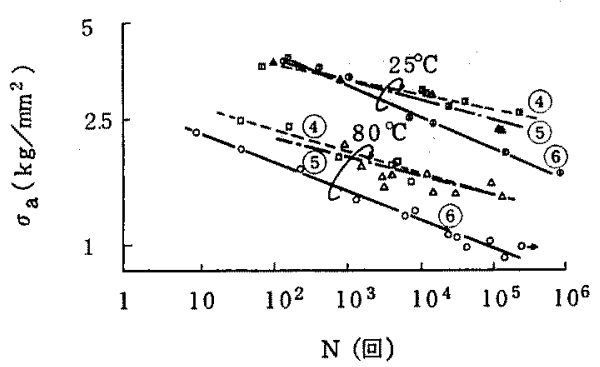

因 5 絶縁 (4) (6) の引張り波学特性

Fig. 5. Tensile fatigue characteristics of insulations (4) (6).

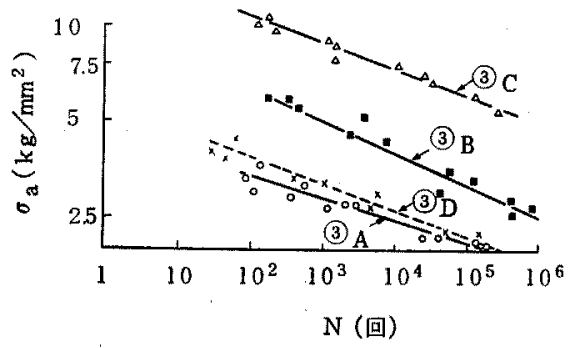

(3) : $10 \mathrm{~mm}$ 幅テープ, (3) $\mathrm{B}: 32 \mathrm{~mm}$ 幅テー-プ, (3) : 平卷, (3D: PTFE テープ卷込 $32 \mathrm{~mm}$ 幅テープ

図 6 絶絲 (3) の引張り疲労特性

Fig. 6. Tensile fatigue characteristics of insulation (3).

ベだ結果を示す。図から引張り疲学特性はテープ幅に 大きく影響を受け，テープ幅が広いほど疲労に強く， また PTFE テープを巻込んだ試料は疲労しやすいと 言える。乙れは図７亿破断の進展経路を示すが，破断

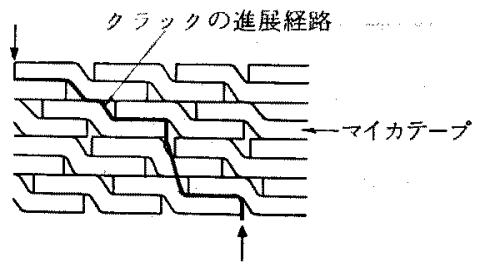

図 7 引張り疲学仗よクラックの進展経路

Fig. 7. Crack propagation path due to tensile fatigue.

はテープの重なり目を縫うようにして最短距離をきれ つが倠展することにより起きるからで，テープ幅が狭 いほどクラックの所要進展距離が短くなり疲労しゃ すくなる。また PTFE テープを巻込んだ陚料では， PTFEとマイカテープの界面がはがれやすいために， クラックの進展距離が見かけ上短くなったと同じ効果 があり，早く破断すると考えら机る。従って，絶縁首 に含浸不良や少化などでボイドができると疲労劣化が 早まることが考えられる。

次に, 図 8 亿絶縁 (1)〜(3)の圧縮疲学特性を示す。図 加ら王縮疲労特性む(1) 式で近似できること，絶縁に より圧縮疲労特性の温度㖪存性がかなり異なり，絶縁 (3) は $80,120^{\circ} \mathrm{C}$ に扣いて王縮疲学特性が絶緑 (1) 飞比 べて劣り，データのばらつきむ大きいこと，また絶縁 (3)を $180^{\circ} \mathrm{C}$ で後硬化した試料は $80,120^{\circ} \mathrm{C}$ においては 疲労少化されにくくなっており，ばらつきむ少なくな っているととがわかる。後硬化により疲労劣化されに くくなったととから，絶縁 (3)の高温での疲労特性が 


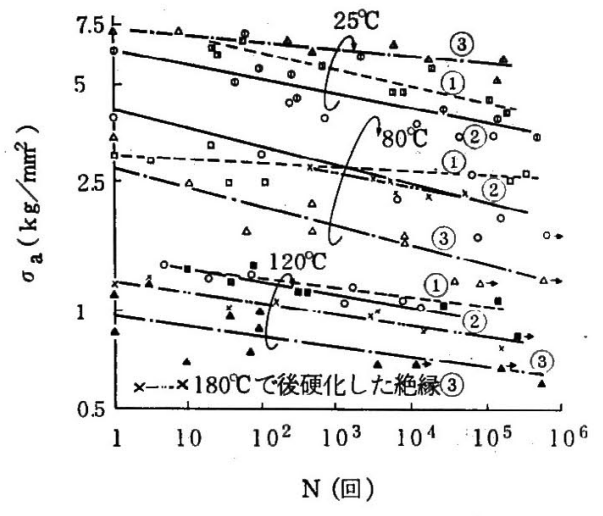

図 8 絶縁 (1)～(3) の厈縮疲労特性

Fig. 8. Compressive fatigue characteristics of insulations (1) (3).

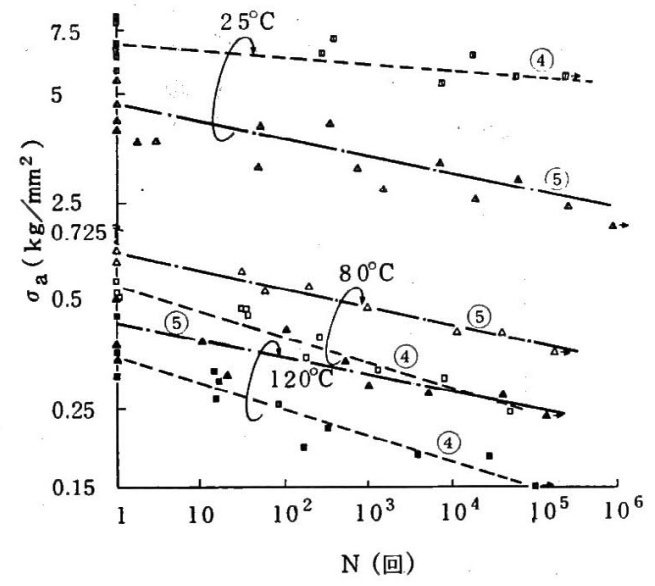

図 9 絶縁 (4), (5) の圧縮疲労特性

Fig. 9. Compressive fatigue characteristics of insulations (4), (5).

劣るのは硬化が不十分なためと思われる。

絶縁 (4), (5) の圧縮疲学特性を図 9 亿示す。図加ら, $25^{\circ} \mathrm{C}$ では全集成マイカの絶縁のほうが集成マイカ, はがしマイカ混用の絶縁より疲学特性が偐れている

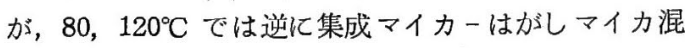
用の絶縁のほうが全集成マイカの絶縁より優れている と言える。絶縁 (5) はタービン発電機において 20 年近 くの優れた運転実綪をむっているが，てれに比べ全集 成マイカの真空加圧含浸絶縁 (1)，(2)，(3)は更に優れ た疲学特性を有していると言える。

なお，図 4 と図 8 , 図 5 と図 9 を比べると，高温化 おいては同じ応力振幅では压縮のほうが引張りより疲 労劣化しやすいととがわかる。

\section{〈3.2〉実規模コイルによるヒートサイクル劣化特} 性ヒートサイクルによる疲学劣化を表わす指標と

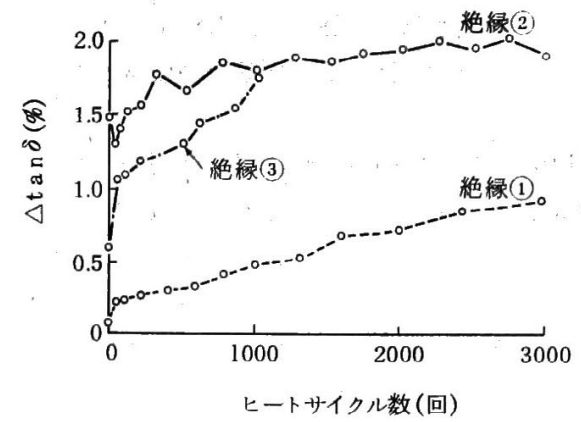

図 10 実規模コイルを使ったヒートサイクル による絶縁 (1) (3)の $\Delta \tan \delta$ の変化

Fig. 10. $\Delta \tan \delta$ change of insulations (1) (3) due to thermal cycles using actual machine coils.

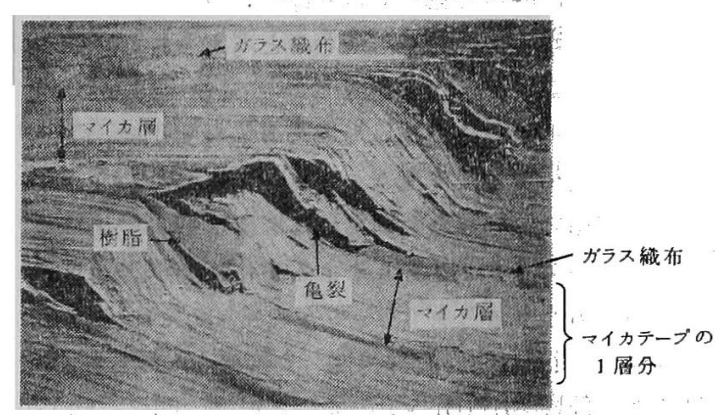

(a) ヒートサイクル漹験 $\left(45^{\circ} \mathrm{C} \rightleftarrows 160^{\circ} \mathrm{C}, 1,000\right.$ 回) 後

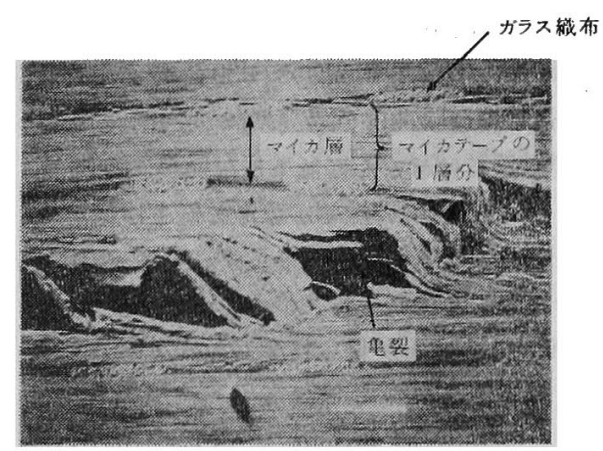

(b) 压宿度学武験 $\left(\sigma_{a}=7.08 \mathrm{~kg} / \mathrm{mm}^{2}, 25^{\circ} \mathrm{C}, 431,366\right.$ 回) 後 図 11 絶縁層に見られたクラック（絶縁 (3)１08×）

Fig. 11. Crack observed in the insulation wall (insulation (3), 108×).

なる $\Delta \tan \delta$ (定格電压と. $3 \mathrm{kV}$ での $\tan \delta$ の差) の 変化を図 10 に示す。四加ら， $\Delta \tan \delta$ の増加は絶縁 (3) が絶縁 (1) に比へ顕著であり, 絶縁 (3)のほうが絶縁 (1) に比ベヒートサイクルによる少化が大きいととがわか る。ヒートサイクル試験を終了したコイルの絶縁層の 絶縁破壊箇所近傍には，図11に示すように絶縁層の 切出し片により圧縮疲学試験を終了した絶縁層に見ら れたむのと極めて良く似た絶縁層のしゅう曲ならびに 
きれつが観察された。㮸って，ヒートサイクルによる コイル絶緣の疲労は，主に圧繀疲爫化基づくもと思 われる。

図10で絶縁 (3)のほうが絶縁 (1)に比べヒートサイ クルによる劣化が大きかったのは、図 8 で絶縁 (3)が絶 椂 (1) に比へ $80^{\circ} \mathrm{C}, 120^{\circ} \mathrm{C}$ に求ける正縮疲学特性加加 なり少る結果と良く刘応している。一般にコイルの上 一トサイクルによる絶縁劣化は，絶緣層の疲学特性の

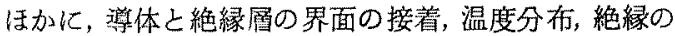
鉄心に対するすべりなどが大きく影響する。ここで， 3種類の絶縁について行なったヒートサイクル試験 は，コイルの寸法，支持固定方法が同じであり，温度 分布鉄心に対するすべりなどはほぼ同じ条件と考えら れる。また，導体と絶縁層の界面の接着は，絶縁層の 疲学特性と類似の性質をむつものと考元られる。従。 て，今回のように異なる絶縁について同一の条件で七 一トサイクル試験を実施した場合の絶縁劣化は，主に 絶縁層の疲労少化に支配されるものと思われる。この 上うな理由で，絶縁層の切出し片に上る疲労少化特性 上コイルのヒートサイクルによる劣化傾向かよく対応 したのであるう。

〈3.3〉 繰返し曲げ疲労特性 絶縁 (3) の繰返し曲 げによる破塄電生 (BDV) の変化と温度の関係を図 12 に示す。ただし，モデル鉄心端部に生ずる最大ひず みは, 室温にて振幅 $\left(\delta_{\mathrm{p}-\mathrm{p}}\right) 10 \mathrm{~mm}$ で $735 \mu, 8 \mathrm{~mm}$ で $575 \mu, 6 \mathrm{~mm}$ で $420 \mu, 4 \mathrm{~mm}$ で $280 \mu$ であった。 $\delta_{\mathrm{p}-\mathrm{p}}=10 \mathrm{~mm}$ で繰返し曲げ回数 $(N)=5 \times 10^{6}$ 回後の BDV は室温付近ではほとんど低下しないが，図 $13 に$ 示すように，この絶縁の弾性率が急激に低下し始める $80^{\circ} \mathrm{C}$ 付近で急激任但下し極小值を示す。更に，BDV は $100^{\circ} \mathrm{C}$ を越えると徐々に低下が少なくなり，130〜 $150^{\circ} \mathrm{C}$ ではほとんど低下が見られなくなり，180 $\mathrm{C} て ゙$

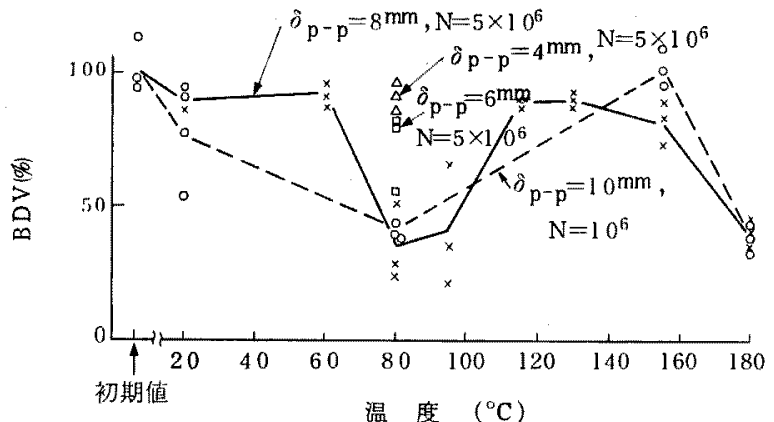

図 12 絶縁 (3)の繰返し曲げ疫学試験後の破罱電圧 (BDV)

Fig. 12. Breakdown voltage of insulation (3) after repeated bending fatigue tests.

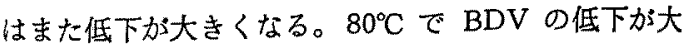
きいというととは，図14に示すように $80^{\circ} \mathrm{C}$ では $N$ の少ない頜域で BDV の低下を生じ，疲当が早く起き ると言い換えることができる。なお，図 12 から $80^{\circ} \mathrm{C}$ における BDVの低下は振幅を小さくすると共に少な くなることすわかる。以上述べた絶縁の弾性率が急激 に低下し始める温度付近でコイル絶縁の繰返し曲げ疲 労に上る劣化が極大になるという傾向は，絶縁 (3)に 限らず他の絶縁にも共通に見られた現象である。

本誠験装置は，図3に示したように供試試料の一部 が恒温槽から露出しているため，加振部とモデル鉄心 部では温度差が生じる。このため，特に設定温度が絶 縁層の弾性率が急激に低下する $80^{\circ} \mathrm{C}$ 付近の温度では， モデル鉄心端部の絶縁にコイルの長手力向に絶縁層の 曲げ弾性率が変化することに起因した応力集中が起 き，疲労劣化が大きくなることが考えられた。そと で，駆動装置も含め繰返し曲げ波学試験装置全体環 境試験室に入れて，コイルの温度を長手方向に均一に

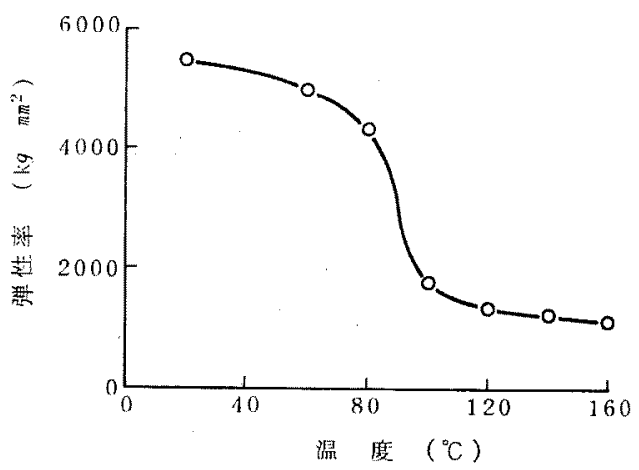

図 13 絶縁 (3)の絶縁層の弾性率の温度依存性 Fig. 13. Temperature dependence of elastic modulus for insulation (3).

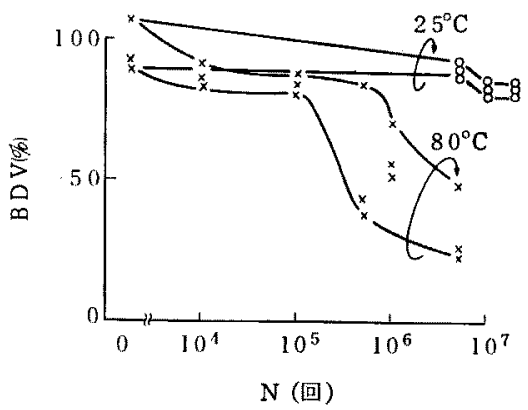

図 14 繰返し曲げ回数と破壊電王の関保

Fig. 14. Relationship between repeated bending cycles and breakdown voltage (BDV). 


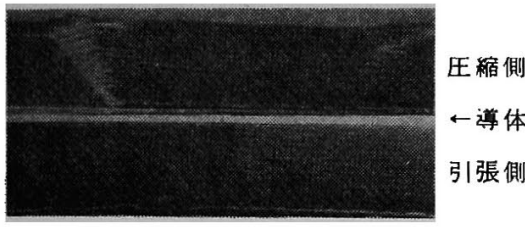

（a） 絶緅 (4) ( $N=5 \times 10^{6}$ 回)

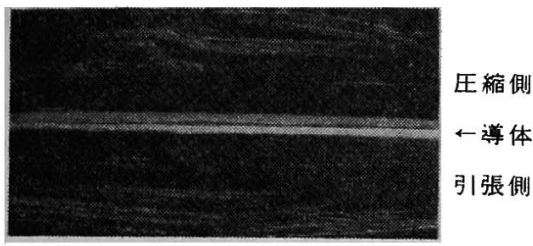

（b） 絶縁 (5) $\left(N=10^{6}\right)$

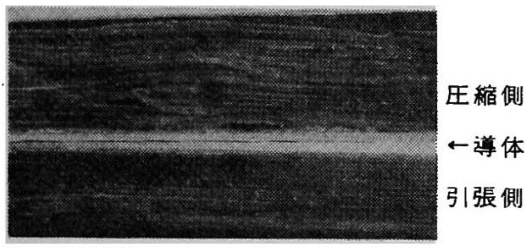

(c) 絶䜌 (6) $\left(N=10^{5}\right)$

絶級 (3), 振幅 $=10 \mathrm{~mm}, N=10^{5}, 80^{\circ} \mathrm{C}, 6.1 \times$

図 15 片振りによる繰返し曲げ疲労後の 絶縁層の断面

Fig. 15. Cross sectional photograph of insulation wall after single sided bending fatigue test.

した条件で試験を行なった。その結果，この場合であ 図 12 と同じ特性が得られることがわかった。なお， 片振りにより行なった試験では, 絶縁 (3)のみならず, マイカ構成の異なる絶縁 (4)〜 (6)のいずれの場合も圧 縮側で絶縁破壊しており，繰返し曲げ疲労による劣化 は压縮疲労により起きるむのと考えられる。

図 $15 に$ ，絶縁 (4)〜(6)の片振りにより繰返し曲げ疲 労を受けた絶縁層の断面写真を示す。試料はいずれす 圧縮側のほうが損傷が顕著であることがわかる。全集 成マイカの絶縁 (4)では, 圧縮疲労によると思われる 絶縁層のしゅう曲ならびに主にマイカテープ間に形成 される樹脂層とマイカとの界面での微小なきれつが局 所的に見られる。一方，はがし マイカ入の絶縁 (5)，(6) では，はがしマイカのへき開によるはく離がかなり広 範囲に見られ，絶縁の著しい膨らみが観察される。

以上の結果を踏まえ, 絶縁の弾性率が急激に低下し 始める温度付近でコイル絶縁の繰返し曲げ疲労による 劣化が極大になるという現象について，絶縁 (3)を例 にとって以下に検討する。繰返し曲げ試験によりモデ ル鉄心端に生じる最大応力 $\sigma_{\max }$ は, 次の.(2) 式から 求めることができる。

$$
\sigma_{\max }=3 E b \delta / 2 l^{2}
$$

表 2 温度と $\sigma_{s} / \sigma_{\max }$ の関係

Table 2. Relationship between temperature and $\sigma_{s} / \sigma_{\max }$.

\begin{tabular}{c|c|c|c}
\hline 温 度 $\left({ }^{\circ} \mathrm{C}\right)$ & $\sigma_{\max }\left(\mathrm{kg} / \mathrm{mm}^{2}\right)$ & $\sigma_{s}\left(\mathrm{~kg} / \mathrm{mm}^{2}\right)$ & $\sigma_{s} / \sigma_{\max }$ \\
\hline 25 & 4.79 & 11.22 & 2.34 \\
60 & 4.38 & 4.80 & 1.10 \\
80 & 3.80 & 2.54 & 0.67 \\
100 & 1.58 & 1.37 & 0.86 \\
120 & 1.18 & 1.29 & 1.09 \\
160 & 0.98 & 1.15 & 1.17 \\
\hline
\end{tabular}

ここで, $E$ : 弾性率 $\left(\mathrm{kg} / \mathrm{mm}^{2}\right), b$ : 試料の厚 さ $(\mathrm{mm}), \delta:$ 駆動部における片側最大変位量 $(\mathrm{mm}), \quad l:$ モデル 鉄心端から駆動部までの距 離 $(\mathrm{mm})$

そてで, 絶縁 (3)について $\delta=4 \mathrm{~mm}$ として (2) 式か ら求めた $\sigma_{\max }$ と, 図 3 のような圧縮疲学特性から $10^{6}$ 回で破断すると推定される応力振幅の 2 倍に等し い圧縮応力 $\sigma s$ とを比較した。

表 2 亿疲労劣化位対する裕度の目安となる $\sigma_{s} / \sigma_{\max }$ と温度の関係を示す。同表の結果は， $\sigma_{s}$ と $\sigma_{\max }$ の温 度依存性が異なるため, 弾性率が急激に低下し始める $80^{\circ} \mathrm{C}$ 付近で $\sigma_{s} / \sigma_{\max }$ が最む小さくなり，乙の温度付 近で圧縮疲労による劣化が最む起きやすいことを示唆 している。表 2 の結果は図 12 の結果と比較的良く対 忍しており，図12のようなコイル絶縁の繰返し曲げ 疲労劣化と温度の関係は，曲げにより絶縁層に発生す る応力とその応力における絶縁層の圧縮疲労特性を反 映したむのと言える。

絶縁層の切出し片による試験は, 試料の作製が容易 でコイルを使った試験に比べ手軽に行なえる。この 試験は，以上述へたとおり絶縁の選別に有用なだけで なく、コイル絶縁のヒートサイクルや繰返し曲げによ る疲労劣化現象を解明するうえでむ有意義である。

\section{4. ま め}

高電圧回転機に使われているエポキシマイカ絶縁の 機械的疲労汇よる劣化特性について, 絶縁層の切出し 片による引張りおよび圧縮疲労試験，実規模コイルの ヒートサイクル試験およびコイル絶縁の繰返し曲げ疲 労試験を行ない比較検討した結果，以下のことが明ら かになった。

ヒートサイクルや振動による劣化は主に圧縮疲学に よるむので，はがしマイカ入絶縁の場合ははがしマイ カのへき開面で，集成マイカ絶縁の場合はマイカテー プ間に形成される樹脂層とマイカとの界面できれつが 発生，進展するために生ずる。一般に絶縁層の引張り および圧縮疲労は温度が高いほど起きやすくなる。た 
だし，一定变位の繰返し曲げ試験の場合，絶緣の弾性

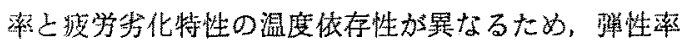
が急激仁低下し始める温度付近で疲学劣化が極大とな る。なお，䋓縁層中の樹脂の硬化が不十分度ため高温

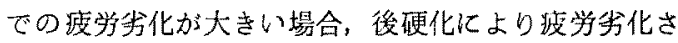
れにくくするととができる。また，絶縁層の切出し片 に上る疲労試験は，乙の結果がコイ儿絶縁のヒートサ イクル試験や繰返し曲げ試駼汇よる結果と良く刘応し ており，簡便な疲労試馱方法として有用である。

これらの結果は, 高酮王回転機絶縁の信頼性问上, 機能評洒法の合理化仪重要な示唆を与えるすので，次 世代の高殗圧回轱機絶縁システムの閶発に役立つもの と確信する。

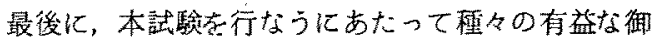

助言を賜わった名古屋大学工学部教授 家田正之先生 亿謝意を表します。

(昭和 59 年 2 月 20 日受付, 同 59 年 10 月 18 日再受付)

\section{文献}

(1) H. Mitsui, K. Yoshida, Y. Inove \& K. Kawahara "Mechanical Degradation of High Voltage Rotating Machine Insulation", IEEE Trans. Elect. Insulation, EI-10, 533 (1981)

(2) H. Mitsui, K. Yoshida, Y. Inoue \& S. Kenjo: "Thermal Cyclic Degradation of Coil Insulation for Rotating Machines," IEEE Trans. Power Apparatus Syst., PAS102, 67 (1983)

（3）三牛・吉田・吉田：「曲げストレス下におりるエポキシマイ

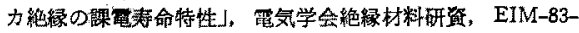
95 (嘫 58-8)

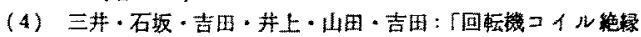

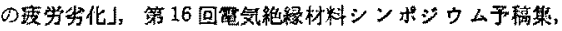
p. 147 (喽 58-9) 